\title{
Nutrient Absorption and Biomass Production by the Marine Diatom Chaetoceros Muelleri: Effects of Temperature, Salinity, Photoperiod, and Light Intensity
}

\author{
Elizerberth Minggat ${ }^{1}$, Wardina Roseli' ${ }^{1}$ Yasuaki Tanaka ${ }^{1 *}$ \\ 1 Environmental and Life Sciences, Faculty of Science, Universiti Brunei Darussalam, Jalan Tungku Link, BE1410, \\ Brunei Darussalam \\ * Corresponding author: yasuaki.tanaka@ubd.edu.bn
}

\begin{abstract}
The marine diatom Chaetoceros muelleri is commonly used for aquacultural feed and is well known for its fast growth and easy maintenance. In order to evaluate the potential of $C$. muelleri to be used for the nutrient removal and biomass production from eutrophic saline wastewaters, the algae were cultured under a wide range of temperature, salinity, photoperiod, and light intensity. The optimum temperature for the biomass production was observed at $30^{\circ} \mathrm{C}$, but the algae could maintain at least $66 \%$ of the highest production between $20^{\circ} \mathrm{C}$ and $35^{\circ} \mathrm{C}$. The optimum salinity for the biomass production was 25 , but the algae could maintain at least $22 \%$ of the highest production between 10 and 30. Both light intensity and photoperiod affected the algal biomass production, and the minimum light requirement was considered $100 \mu \mathrm{mol} \mathrm{m} \mathrm{m}^{-2} \cdot \mathrm{s}^{-1}$ for 6 hours to maintain the biomass production and nitrogen $(\mathrm{N})$ and phosphorus $(\mathrm{P})$ absorption. Throughout all the experiments, the $\mathrm{N}$ and $\mathrm{P}$ absorption increased with the biomass production, but the ratio of $\mathrm{N}$ and $\mathrm{P}$ to the biomass exponentially decreased with the biomass production. These results showed that $C$. muelleri is tolerant to the wide range of environmental conditions, absorbing nutrients and producing organic matter. C. muelleri has a great potential to be introduced in the water treatment processes, especially where the temperature and salinity fluctuate.
\end{abstract}

Keywords: microalgae, bioremediation, wastewater, eutrophication, estuary, brackish water, aquaculture

\section{INTRODUCTION}

The effects of human activities on aquatic environmental pollution have been a growing concern due to the disposal of wastewaters from various sources [Ummalyma et al. 2018]. In order to minimize the risk of aquatic ecosystem deterioration, wastewater treatments are the essential process before the water is discharged to the natural environment. Because conventional physical and chemical water treatments come with the problems of expensive cost and high energy demand [Mccarty et al. 2011], the bioremediation technologies have been developed as an alternative, eco-friendly approach. In order to efficiently remove nutrients, organic pollutants, and heavy metals from wastewaters, the potential of various aquatic organisms (e.g., fungi, bacteria, microalgae, macroalgae) for bioremediation has been evaluated [Kues 2015; Mondal et al. 2019; Zhi et al. 2019; Tanaka et al. 2020]. Compared with bacteria or fungi, microalgae and macroalgae have the absolute advantage of quickly absorbing inorganic nutrients from water, producing the algal biomass from photosynthesis. The produced algae can be easily collected and separated from the water because of its larger size than bacteria or fungi.

Among all the known sources of biomass energy, microalgae show the highest potential as a feedstock for the production of biofuel because they have higher biomass production than macroalgae or vascular plants, accumulating up to 20-50\% lipid content [Chisti 2007; Driver et al. 2014; Klein-Marcuschamer et al. 2013; Rai et al. 2015]. The production of biofuel from microalgae 
has been studied well, but because of the continuous requirement of nutrient and $\mathrm{CO}_{2}$ supplies, the microalgae-derived biofuel production is still too expensive to industrialize at present [Pate et al. 2011; Yang et al. 2011; Hong et al. 2013]. Therefore, cultivating microalgae for obtaining not a single but multiple benefits simultaneously is receiving growing attention [Mandal, Mallick 2010; Guo et al. 2013; Caporgno et al. 2015; Aslam et al. 2020]. One of the most hopeful combinations is the production of the algal biomass for biofuel and the removal of nutrients from wastewater [Ansari et al. 2017; Abinandan et al. 2018]. However, most of previous studies evaluated the freshwater microalgae such as Chlorella [Li et al. 2011; Yang et al. 2011; Ansari et al. 2017; Abinandan et al. 2018], but not focused on the potential of salt-tolerant microalgae such as marine diatoms, though many types of wastewater or eutrophic environmental water contain salts [Gengmao et al. 2010; Datta et al. 2019].

Chaetoceros muelleri is a marine diatom that is ubiquitously distributed worldwide. Because of its fast growth and easy maintenance, C. muelleri has been used in aquaculture as feed for zooplankton and shrimp larvae at commercial hatcheries in many regions [Wang et al. 2014; Malibari et al. 2018], making this species as one of the most important microalgae in the aquacultural industry [Lopez-Elias et al. 2005; Wang et al. 2014; Rahmadi et al. 2020]. Another reason that C. muelleri has been frequently used in aquaculture is its adaptation to salinity change [Fujii et al. 1995; Barros et al. 2014; Rahmadi et al. 2020], which is likely to often occur in the land-based aquacultural ponds. Though the growth of Chaetoceros spp. has been studied under various conditions from ecological and aquacultural aspects [Harrison et al. 1990; Leonardos and Geider 2004; Magnotti et al. 2016], the potential of C. muelleri to be used for bioremediation and biomass production has been scarcely studied [Rahmadi et al. 2020].

The present study aimed to evaluate the potential of C. muelleri to be used for the bioremediation (nutrient removal) and biomass production from saline and brackish wastewaters. From the aspects of the double benefits, the algae were cultured to study the effects of fundamental environmental factors (salinity, temperature, photoperiods, and light intensity) under laboratory conditions. This study would be the first that tried to apply $C$. muelleri, which has been recognized well in aquaculture, to the saline and brackish wastewater treatment for wider applications.

\section{MATERIALS AND METHODS}

The marine diatom, Chaetoceros muelleri, was supplied by the Broodstock Development Centre (Department of Fisheries, Ministry of Primary Resources and Tourism) in Brunei Darussalam in December 2019. The diatom had been kept in the center for many months as feed used for the shrimp aquaculture. Natural seawater, which had a salinity of 30 , was collected from the coastal sea of Brunei Darussalam and was sterilized before use. The diatom was inoculated in sterilized natural seawater supplemented with the $f / 2$ medium [Guillard, Ryther 1962] and was maintained at a room temperature (approximately $22-24^{\circ} \mathrm{C}$ ) under fluorescent lights (the light intensity: $100 \mu \mathrm{mol} \mathrm{m} \mathrm{m}^{-2} \cdot \mathrm{s}^{-1}$ ) with the light:dark (L:D) cycles of 12:12 hours in the laboratory of Universiti Brunei Darussalam. This algal stock solution was renewed every week for the following experiments by transferring a portion of the algal solution to a new seawater medium.

\section{Temperature}

The sterilized natural seawater (salinity 30 ) was enriched with the $\mathrm{f} / 2$ medium, and ammonium chloride $\left(\mathrm{NH}_{4} \mathrm{Cl}\right)$ and sodium bicarbonate $\left(\mathrm{NaHCO}_{3}\right)$ were also added to elevate its concentration by $100 \mu \mathrm{mol} \cdot \mathrm{L}^{-1}$ and $4.8 \mathrm{mmol} \cdot \mathrm{L}^{-1}$, respectively, to promote the growth of the algae. The seawater medium $(225 \mathrm{~mL})$ and the algal stock solution $(25 \mathrm{~mL})$ were added to each culture bottle (total volume $250 \mathrm{~mL}$ ), and 20 culture bottles were prepared in total. These 20 bottles were randomly allocated to five water baths ( $\mathrm{n}=4$ for each treatment bath), where the temperature was controlled at $20,25,30,35$, and $40^{\circ} \mathrm{C}$, using submersible heaters. The cultures were subjected to the light intensity of $100 \mu \mathrm{mol} \mathrm{m} \mathrm{m}^{-2} \cdot \mathrm{s}^{-1}$ using white LED lights and 12:12 hours of L:D cycles for 7 days. For all of the experiments in the present study, the underwater aeration was not provided, and all bottles were shaken manually at least twice per day to keep the algae suspended in the medium. 


\section{Salinity}

After the optimum temperature range was determined in the above-mentioned experiment, the next set of 20 bottles were prepared similarly to test the effects of salinity: sterilized natural seawater (salinity 30 ) was mixed with distilled water to prepare culture media with five different salinities $(10,15,20,25$ and $30, n=4$ for each treatment). The culture medium $(225 \mathrm{~mL})$ and the algal stock solution $(25 \mathrm{~mL})$ were added to each culture bottle (total volume $250 \mathrm{~mL}$ ). The cultures were maintained at the most optimum temperature, using submersible heaters, under the light intensity of $100 \mu \mathrm{mol} \mathrm{m}{ }^{-2} \cdot \mathrm{s}^{-1}$ using white LED lights and 12:12 hours of L:D cycles for 7 days.

\section{Photoperiod}

After an optimum salinity was determined in the above-mentioned experiment, new culture media with the most optimum salinity were prepared, and $12 \mathrm{~mL}$ of the algal solution and $238 \mathrm{~mL}$ of the sterilized seawater were mixed to have a total volume of $250 \mathrm{~mL}$ for each bottle. Twenty bottles were prepared in total and were placed under four different L:D cycles (24:00, $18: 06,12: 12$ and $06: 18, \mathrm{n}=5$ per treatment) with the light intensity of $100 \mu \mathrm{mol} \mathrm{m} \mathrm{m}^{-2} \cdot \mathrm{s}^{-1}$ for 7 days using white LED lights. Photoperiods were managed automatically using a timer switch. The cultures were maintained at $25^{\circ} \mathrm{C}$ for 7 days in the same way as above.

\section{Light intensity}

New culture media with the most optimum salinity were prepared, and $8 \mathrm{~mL}$ of the algal solution and $242 \mathrm{~mL}$ of the sterilized seawater were mixed to have a total volume of $250 \mathrm{~mL}$ for each culture bottle. Twenty bottles were prepared in total, and they were placed under white LED lights, having four different light intensities $(10,50,100$ and $170 \mu \mathrm{mol} \mathrm{m}{ }^{-2} \cdot \mathrm{s}^{-1}, \mathrm{n}=5$ per treatment) for $\mathrm{L}: \mathrm{D}$ cycles of $12: 12 \mathrm{~h}$. The light intensity was measured with a light meter (LI-COR LI-250) and was adjusted by changing the distance between the light and culture bottles. The cultures were maintained at $25^{\circ} \mathrm{C}$ for 7 days in the same way as above.

\section{Sampling and analysis}

After 7 days of cultivation, the cultured solutions were filtered through a combusted and preweighted glass fiber filter (Whatman GF/F, diameter $47 \mathrm{~mm}$, pore size $0.7 \mu \mathrm{m}$ ). The filter paper was rinsed with distilled water to remove salts and placed on a sterile petri dish using clean forceps. Then, the filter papers were completely dried in an oven at $50^{\circ} \mathrm{C}$ for 6 hours or until a constant weight was achieved. The filters were cooled to a room temperature and the dry weight was measured using an analytical balance with a precision of $0.1 \mathrm{mg}$. The dry weight of the algal biomass was then calculated by subtracting the initial dry weight of the filter and was normalized to a unit volume of water $\left(\mathrm{mg} \mathrm{L}^{-1}\right)$. The algal biomass was also measured for the initial algal stock solution. The production of the algal biomass during the culture experiment was calculated as follows:

Biomass production $=\frac{D W_{e}-D W_{i}}{t}, \mathrm{mg} \mathrm{L}^{-1} \cdot \mathrm{d}^{-1}$

where: $D W_{i}$ and $D W_{e}$ are the dry algal biomass $\left(\mathrm{mg} \mathrm{L}^{-1}\right)$ at the start (day 0) and end (day 7) of the culture experiment, respectively, and $t$ is the duration of the culture (7 days).

Because the algal biomass was measured only for the stock solution at day 0 , the initial algal biomass $\left(D W_{i}\right)$ in the culture bottles was calculated from the dilution ratio of the algal solution.

In order to determine the nitrogen $(\mathrm{N})$ and phosphorus (P) content in the microalgae, two small disks were cut out from each sample filter using a hole punch for papers. Each disk contained $2 \%$ of the whole biomass on the filter. Each disk was then placed into a $10 \mathrm{~mL}$ glass tube with $10 \mathrm{~mL}$ of the oxidizing reagent $\left(1 \% \mathrm{~K}_{2} \mathrm{~S}_{2} \mathrm{O}_{8}\right)$, and the solution was autoclaved at $121^{\circ} \mathrm{C}$ for 1 hour to oxidize all $\mathrm{N}$ and $\mathrm{P}$ into nitrate and phosphate, respectively [Raimbault et al. 1999; Miyajima et al. 2005]. As standards, the solutions of potassium nitrate $\left(\mathrm{KNO}_{3}\right)$ and potassium dihydrogen phosphate $\left(\mathrm{KH}_{2} \mathrm{PO}_{4}\right)$ were also prepared and processed at the same time. After the solutions were cooled to a room temperature, $5 \mathrm{~mL}$ were used to measure the nitrate concentration from the absorbance at $220 \mathrm{~nm}$ [Collos et al. 1999], using a spectrophotometer (Shimadzu UV-1800). The 
phosphate concentration was determined using the molybdate and ascorbic solutions, according to Hansen and Koroleff [1999]. After determining the amount of $\mathrm{N}$ and $\mathrm{P}$ in each disk, total $\mathrm{N}$ and $P$ content in the whole filter were calculated and then, the percent ratio of the $\mathrm{N}$ and $\mathrm{P}$ content (mg) to the total algal dry weight (mg) was calculated ( $\mathrm{N} \%$ and $\mathrm{P} \%$, respectively). The $\mathrm{N}$ and $\mathrm{P}$ absorption rates were calculated by multiplying the biomass production by $\mathrm{N} \%$ and $\mathrm{P} \%$, respectively.

\section{Statistical analyses}

The relationships between the treatment factors (temperature, salinity, photoperiod, and light intensity) and the algal parameters (biomass production, $\mathrm{N} \%, \mathrm{P} \%, \mathrm{~N}: \mathrm{P}, \mathrm{N}$ and $\mathrm{P}$ absorption) were tested by the regression analyses. The linear, quadratic, hyperbolic, and exponential regression analyses were performed for each parameter using SigmaPlot 12.5 (Systat Software, San Jose, CA). Only for the salinity treatment, the Loretzian regression was applied to the biomass production, $\mathrm{N} \%$, and $\mathrm{P} \%$, because other regressions did not fit well, obviously. The regression analysis that resulted in the lowest root mean squared error (RMSE) and that was statistically significant $(p<0.05)$ is shown in the results and figures.

\section{RESULTS AND DISCUSSION}

From the experiment on temperature, the algal biomass production was highest at approximately $30^{\circ} \mathrm{C}$ and lower at higher or lower temperatures (Fig. 1a). The maximum biomass production was estimated to be $31 \mathrm{mg} \mathrm{L}^{-1} \cdot \mathrm{d}^{-1}$ at $28^{\circ} \mathrm{C}$ from the quadratic regression (Table 1). Though the algal production drastically declined to $10 \mathrm{mg} \mathrm{L} \mathrm{L}^{-1} \cdot \mathrm{d}^{-1}$ at $40^{\circ} \mathrm{C}$, it could maintain at least $66 \%$ of the maximum production between $20^{\circ} \mathrm{C}$ and $35^{\circ} \mathrm{C}$, which shows a strong tolerance of the algae to the wide range of temperature. Most tropical microalgae decline their growth above $30^{\circ} \mathrm{C}$ or $33^{\circ} \mathrm{C}$, but only Chaetoceros sp. was reported to be tolerant to a higher temperature $\left(33-35^{\circ} \mathrm{C}\right)$ [Renaud et al. 2002], which is consistent with the present observation. Even at $40^{\circ} \mathrm{C}$, the present algae were able to steadily increase the biomass with time, which was estimated from the time-course change of the optical density of the cultured water at $750 \mathrm{~nm}$ (data not shown).
The algal N\% and $\mathrm{P} \%$ showed a contrasting pattern to the biomass production (Fig. 1b, c). The reduction of $\mathrm{N} \%$ and $\mathrm{P} \%$ with the increasing biomass production would be attributed to the relative increase in the storage compounds such as carbohydrates in the algae because of the enhanced photosynthetic $\mathrm{C}$ fixation under optimum temperature conditions. Similar contrasting patterns were observed for Chaetoceros sp. [Renaud 2002], Chaetoceros calcitrans [Raghavan et al. 2008], and Spirulina maxima and Spirulina platensis [Oliveira et al. 1999]. On the other hand, the N:P ratio and the $\mathrm{N}$ and $\mathrm{P}$ absorption were not affected by the temperatures, and the mean values were $6.4,0.40 \mathrm{mg} \mathrm{L}^{-1} \cdot \mathrm{d}^{-1}$, and $0.14 \mathrm{mg} \mathrm{L}^{-1} \cdot \mathrm{d}^{-1}$, respectively (Fig. 1d-f). These results showed that the algae were able to keep synthesizing the functional compounds (e.g., proteins and phospholipids) under the studied range of temperature.

From the experiment on salinity, the algal biomass production was highest at salinity 25 and lowest at salinity 10 (Fig. 1g). Using the regression model with a peak, the maximum biomass production was estimated to be $39 \mathrm{mg} \mathrm{L}^{-1} \cdot \mathrm{d}^{-1}$ at salinity 27 , while the lowest production was $8.5 \mathrm{mg} \mathrm{L}^{-1} \cdot \mathrm{d}^{-1}$ at salinity 10 (Table 1 ). The range of optimum salinity observed in the present study (25-30) was consistent with the previous reports on the same algal species [Barros et al. 2014; Rahmadi et al. 2020]. Microalgae expend energy to maintain the turgor pressure in their cells at salinity below and above the optimum, which results in a reduction in photosynthesis, biomass productivity, or cell division [Salama et al. 2014]. However, it should be noted that though the growth declined, the algae could maintain $36 \%, 25 \%$, and $22 \%$ of the maximum biomass production at salinity 20,15, and 10, respectively (Fig. $1 \mathrm{~g}$ ). The growth reduction was almost negligible at salinity 15 , compared to 25 in a recent study using a continuous photobioreactor [Rahmadi et al. 2020]. This tolerance to the wide range of salinity would be advantageous for bioremediation or nutrient recovery from the saline or brackish wastewater, which has been scarcely studied so far [Gengmao et al. 2010].

Along with the experiment on temperature, the algal $\mathrm{N} \%$ and $\mathrm{P} \%$ showed a contrasting pattern to the biomass production in the experiment on salinity (Fig. 1h, i). However, unlike the temperature experiment, the algal N:P ratio 

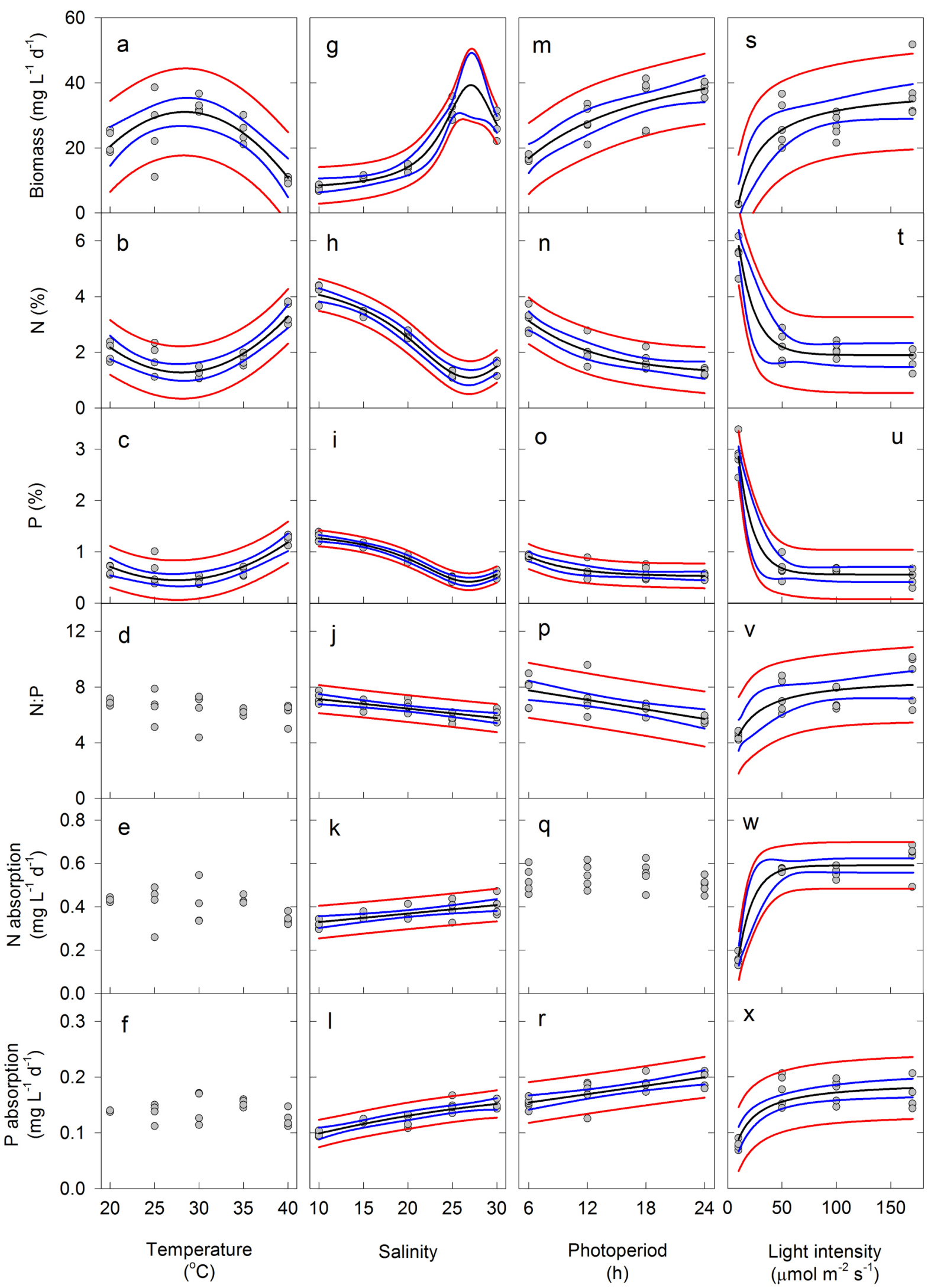

Fig. 1. The effects of temperature (a-f), salinity (g-l), photoperiod (m-r), and light intensity (s-x) on the biomass production, nutrient content ( $\mathrm{N} \%, \mathrm{P} \%, \mathrm{~N}: \mathrm{P})$, and nutrient absorption by Chaetoceros muelleri. Black, blue, and red lines indicate the regression line, 95\% confidence bands, and 95\% prediction bands, respectively. The formulae of the regression lines are listed in Table 1. 


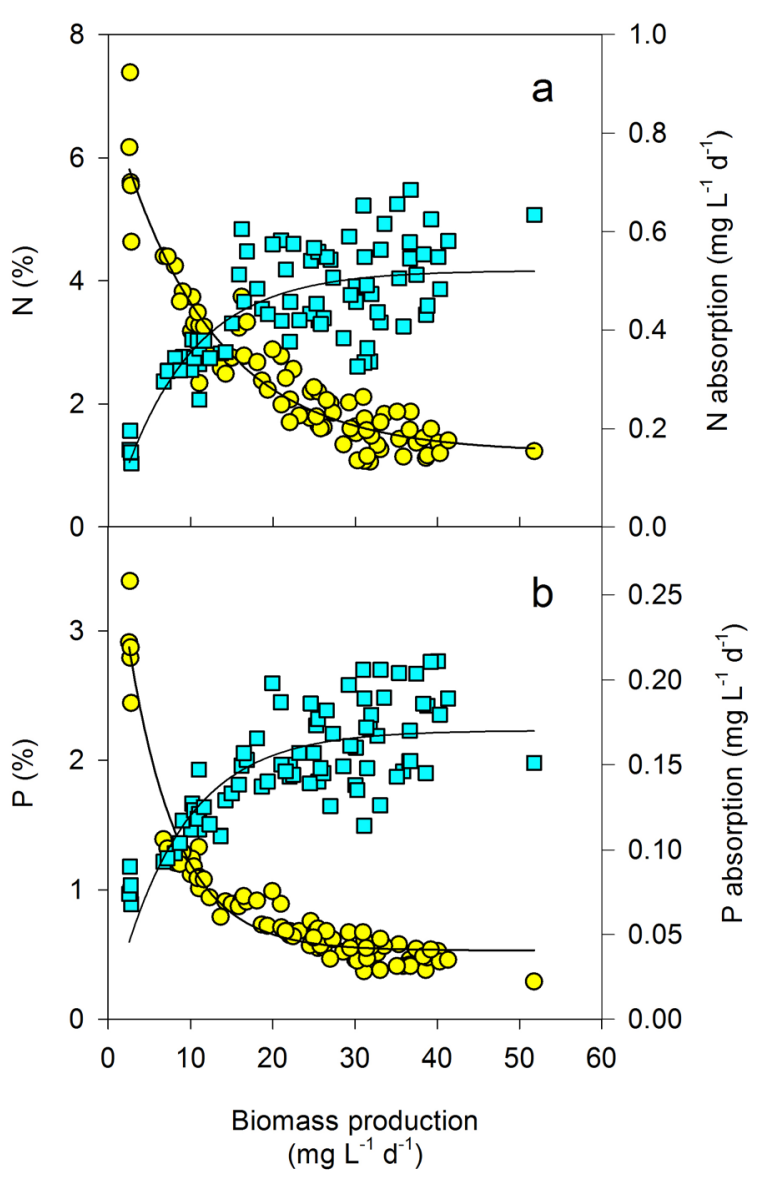

Fig. 2. The relationship (a) between the biomass production and $\mathrm{N}$ content (circle) and absorption (square) as well as (b) between the biomass production and $\mathrm{P}$ content (circle) and absorption (square)

$\mathrm{N}(\%): \mathrm{y}=5.73 \mathrm{e}^{-0.0859 \mathrm{x}}+1.21\left(r^{2}=0.90, p<0.0001\right)$

$\mathrm{N}$ absorption: $\mathrm{y}=0.521\left(1-\mathrm{e}^{-0.114} \mathrm{x}\right)\left(r^{2}=0.61\right.$, $p<0.0001)$

$\mathrm{P}(\%): \mathrm{y}=3.59 \mathrm{e}^{-0.168 \mathrm{x}}+0.532\left(r^{2}=0.95, p<0.0001\right)$

$\mathrm{P}$ absorption: $\mathrm{y}=0.170\left(1-\mathrm{e}^{-0.122} \mathrm{x}\right)\left(r^{2}=0.60\right.$, $p<0.0001)$

slightly increased and the $\mathrm{N}$ and $\mathrm{P}$ absorption decreased along with salinity (Fig. 1j-1, Table 1). These results show that the biochemical composition of the algal cells was altered by low salinity stress; for example, a relative decrease in phospholipids to proteins with decreasing salinity [Renaud and Parry 1994; Bartley et al. 2013; Benavente-Valdés et al. 2016]. However, the lowest $\mathrm{N}$ and $\mathrm{P}$ absorption (salinity 10) still maintained $80 \%$ and $64 \%$ of the highest absorption (salinity 30 ), respectively, which suggests that the capability of the algae to absorb $\mathrm{N}$ and $\mathrm{P}$ is more resistant to low salinity stress than its biomass production (Fig. 1g).

Different photoperiods and light intensities caused similar effects on the algal biomass production and nutrient content: the biomass production was described with a hyperbolic regression (Fig. 1m, s), and the N\% and $\mathrm{P} \%$ increased exponentially with decreasing light availability (Fig. 1n, o, t, u). Though the cycles of light and dark conditions, instead of continuous lighting, have a potential to mitigate photoinhibition [Krzeminska et al. 2014], photoinhibition was not observed in the present experiments. The low half-saturation constant for the light intensity (13 $\mu \mathrm{mol} \mathrm{m} \mathrm{m}^{-2} \mathrm{~s}^{-1}$ ) would be due to the acclimation of the algae to the laboratory conditions for many months before the experiment.

It should be noted that the algal N:P ratio increased under the short photoperiod of $6 \mathrm{~h}$, but contrastingly decreased under the low light intensity of $10 \mu \mathrm{mol} \mathrm{m}^{-2} \cdot \mathrm{s}^{-1}$ (Fig. $1 \mathrm{p}, \mathrm{v}$ ). The decline of the N:P ratio at the extremely low light intensity indicates that the nutrient uptake, especially the $\mathrm{N}$ uptake (Fig. 1w), was almost stopped because of the lack of light-derived metabolic energy and consequently, only minimum proteins or enzymes were maintained in the algal cells [Harrison et al. 1990; Meseck et al. 2005]. On the other hand, the $\mathrm{N}$ uptake was maintained constant (mean for all photoperiods: $0.53 \mathrm{mg} \mathrm{L}^{-1} \cdot \mathrm{d}^{-1}$; Fig. 1q) even under the shortest photoperiod, while the $\mathrm{P}$ absorption slightly decreased, which might have resulted in an increase in the proportion of proteins [Harrison et al. 1990; Leonardos and Geider 2004] as seen in the increasing N:P ratio with decreasing photoperiods (Fig. 1p-r). Thus, the irradiation of $100 \mu \mathrm{mol} \mathrm{m} \mathrm{m}^{-2} \cdot \mathrm{s}^{-1}$ for $6 \mathrm{~h}$ would have been sufficient for the algae to maintain the $\mathrm{N}$ uptake and metabolism, though photosynthetic $\mathrm{C}$ fixation and $\mathrm{P}$ absorption declined (Fig. 1m, q, r).

Throughout all of the present experiments, the N\% and P\% exponentially declined with the biomass production, while the $\mathrm{N}$ and $\mathrm{P}$ absorption exponentially rose to the maximum rate with the increasing biomass production (Fig. 2). These relationships indicate that the nutrient uptake might be a limiting step for the biomass production, causing a reduction of the $\mathrm{N}$ and $\mathrm{P}$ content in the algae. Though the culture waters were not continuously shaken in the present laboratory experiments, continuous movement of culture waters, such as using aeration in the bottle, might enhance the algal $\mathrm{N}$ and $\mathrm{P}$ uptake by thinning a nutrient diffusion layer around the algal cell [Sobczuk et al. 2006]. However, this mass transfer limitation becomes less important than kinetic control 
Table 1. Regression analyses of the relationship between the treatments (x: temperature, salinity, photoperiod, and light intensity) and algal parameters (y: biomass production, N\%, P\%, N:P, and $\mathrm{N}$ and $\mathrm{P}$ absorption) for Chaetoceros muelleri.

\begin{tabular}{|c|c|c|c|}
\hline Parameters & Regression & $p$ & $r^{2}$ \\
\hline \multicolumn{4}{|c|}{ Temperature } \\
\hline Biomass production & $y=-0.151 x^{2}+8.55-90.3$ & 0.0002 & 0.63 \\
\hline $\mathrm{N} \%$ & $y=0.014 x^{2}-0.786 x+12.3$ & $<0.0001$ & 0.77 \\
\hline $\mathrm{P} \%$ & $y=0.005 x^{2}-0.259 x+4.01$ & $<0.0001$ & 0.73 \\
\hline $\mathrm{N}: \mathrm{P}$ & Not significant & - & - \\
\hline $\mathrm{N}$ absorption & Not significant & - & - \\
\hline P absorption & Not significant & - & - \\
\hline \multicolumn{4}{|c|}{ Salinity } \\
\hline Biomass production & $y=32.4 /\left(1+((x-27.1) / 3.77)^{2}\right)+6.98$ & $<0.0001$ & 0.95 \\
\hline $\mathrm{N} \%$ & $y=-3.79 /\left(1+((x-26.9) / 8.88)^{2}\right)$ & $<0.0001$ & 0.96 \\
\hline $\mathrm{P} \%$ & $y=-1.03 /\left(1+((x-26.9) / 7.81)^{2}\right)$ & $<0.0001$ & 0.96 \\
\hline $\mathrm{N}: \mathrm{P}$ & $y=-0.068 x+7.81$ & 0.0001 & 0.56 \\
\hline $\mathrm{N}$ absorption & $y=0.004 x+0.290$ & 0.0016 & 0.44 \\
\hline P absorption & $y=-5.29 \times 10^{-5} x^{2}+0.005 x+0.056$ & $<0.0001$ & 0.79 \\
\hline \multicolumn{4}{|c|}{ Photoperiod } \\
\hline Biomass production & $y=65.2 x /(9.43+x)-8.60$ & $<0.0001$ & 0.78 \\
\hline $\mathrm{N} \%$ & $y=4.38 e^{-0.136 x}+1.19$ & $<0.0001$ & 0.81 \\
\hline $\mathrm{P} \%$ & $y=1.40 e^{-0.214 x}+0.525$ & $<0.0001$ & 0.70 \\
\hline $\mathrm{N}: \mathrm{P}$ & $y=-0.114 x+8.45$ & 0.0011 & 0.46 \\
\hline $\mathrm{N}$ absorption & Not significant & - & - \\
\hline P absorption & $y=0.003 x+0.139$ & 0.0002 & 0.55 \\
\hline \multicolumn{4}{|c|}{ Light intensity } \\
\hline Biomass production & $y=63.0 x /(13.4+x)-24.2$ & $<0.0001$ & 0.81 \\
\hline $\mathrm{N} \%$ & $y=7.58 e^{-0.065 x}+1.90$ & $<0.0001$ & 0.90 \\
\hline $\mathrm{P} \%$ & $y=4.83 e^{-0.073 x}+0.556$ & $<0.0001$ & 0.96 \\
\hline $\mathrm{N}: \mathrm{P}$ & $y=6.77 x /(16.9+x)+1.99$ & 0.0002 & 0.63 \\
\hline $\mathrm{N}$ absorption & $y=0.904\left(1-e^{-0.074 x}\right)-0.314$ & $<0.0001$ & 0.94 \\
\hline P absorption & $y=0.193 x /(12.1+x)$ & $<0.0001$ & 0.72 \\
\hline
\end{tabular}

under the nutrient-enriched conditions [Sanford and Crawford 2000]. Because the present study used a common $\mathrm{f} / 2$ medium, nutrient concentration was high enough and therefore, the $\mathrm{N}$ and $\mathrm{P}$ absorption in the present study might have been largely controlled by the kinetic reaction in the algal metabolism.

Overall, the present study showed a tolerance of $C$. muelleri to a wide range of temperature, salinity, photoperiod, and light intensity for the nutrient absorption and biomass production. This high tolerance to various environmental conditions would be useful in the water treatment processes, especially for estuaries, where these environmental conditions often fluctuate due to mixing with seawater and river water. For the wastewaters from land-based aquaculture or from sewage treatment plants, many species of seaweeds (e.g., Gracilaria caudate, Gracilaria crassa, Ulva fasciata, Ulva lactuca,
Ulva ohnoi, and Ulva reticulata) have been tested for removing nutrients from the water, but the removal performance of the seaweeds was strongly affected by salinity, temperature, and nutrient concentration [Msuya and Neori 2002; Marinho-Soriano et al. 2009; Lawton et al. 2013; Sode et al. 2013]. For example, $G$. caudate decreased its growth by more than $80 \%$ when the salinity decreased to 24 [MarinhoSoriano et al. 2009], which is a much drastic reduction, compared to the response of C. muelleri observed in the present study. Microalgae have also been tested for removing nutrients from the wastewater of freshwater aquaculture [Ansari et al. 2017], but rarely of the seawater aquaculture [Magnotti et al. 2016]. It would be required to further evaluate the potential of $C$. muelleri to purify eutrophicated saline water, producing the organic biomass, by conducting larger-scale experiments in the future. 


\section{Acknowledgments}

We are grateful to Nadhirah Lamit (Universiti Brunei Darussalam) and Khoo Tek Ying (Department of Fisheries, Brunei Darussalam) for supporting and setting up the experiments. This study was financially supported by the research grants (No. CRGWG(013)/170601 and UBD/RSCH/ URC/NIG/4.0/2020/001) funded by Universiti Brunei Darussalam.

\section{REFERENCES}

1. Abinandan, S., Subashchandrabose, S.R., Venkateswarlu, K., Megharaj, M. 2018. Nutrient removal and biomass production: advances in microalgal biotechnology for wastewater treatment. Critical Reviews in Biotechnology, 38(8), 1244-1260. doi: 10.1080/07388551.2018.1472066.

2. Ansari, F.A., Singh, P., Guldhe, A., Bux, F. 2017. Microalgal cultivation using aquaculture wastewater: Integrated biomass generation and nutrient remediation. Algal Research, 21, 169-177. doi: 10.1016/j.algal.2016.11.015

3. Aslam, A., Fazal, T., Uz-Zaman, Q., Shan, A., Rehman, F., Iqbal, J., Rashid, N., Rehman, M. S. U. 2020. Biorefinery of microalgae for nonfuel products, Microalgae Cultivation for Biofuels Production, 197-209. doi: 10.1016/ b978-0-12-817536-1.00013-8

4. Barros, M. U., Coelho, A. A., Silva, J. W., Bezerra, J. H., Moreira, R. T., Farias, W. R., Moreira, R. L. 2014. Lipid content of marine microalgae Chaetoceros muelleri Lemmermann (Bacillariophyceae) grown at different salinities. Biotemas, 27(2), 1. doi: 10.5007/2175-7925.2014v27n2p1

5. Bartley, M. L., Boeing, W. J., Corcoran, A. A., Holguin, F. O., Schaub, T. 2013. Effects of salinity on growth and lipid accumulation of biofuel microalga Nannochloropsis salina and invading organisms. Biomass and Bioenergy, 54, 83-88. doi: 10.1016/j. biombioe.2013.03.026

6. Benavente-Valdés, J. R., Aguilar, C., ContrerasEsquivel, J. C., Méndez-Zavala, A., Montañez, J. 2016. Strategies to enhance the production of photosynthetic pigments and lipids in chlorophycae species. Biotechnology Reports, 10, 117-125. doi: 10.1016/j.btre.2016.04.001

7. Caporgno, M. P., Taleb, A., Olkiewicz, M., Font, J., Pruvost, J., Legrand, J., Bengoa, C. 2015. Microalgae cultivation in urban wastewater: nutrient removal and biomass production for biodiesel and methane. Algal Research, 10, 232-239. doi: 10.1016/j.algal.2015.05.011
8. Chisti, Y. 2007. Biodiesel from microalgae. Biotechnology Advances, 25(3), 294-306. doi: 10.1016/j. biotechadv.2007.02.001

9. Collos, Y., Mornet, F., Sciandra, A., Waser, N., Larson, A., Harrison, P. J. 1999. An optical method for the rapid measurement of micromolar concentrations of nitrate in marine phytoplankton cultures. Journal of Applied Phycology, 11(2), 179-184. doi: 10.1023/a:1008046023487

10. Datta, A., Marella, T. K., Tiwari, A., Wani, S. P. 2019. The diatoms: from eutrophic indicators to mitigators. Application of Microalgae in Wastewater Treatment, 19-40. doi: 10.1007/978-3-030-13913-1_2

11. Driver, T., Bajhaiya, A. Pittman, J. K. 2014. Potential of bioenergy production from microalgae. Current Sustainable Renewable Energy Report, 1(3), 94-103. doi: 10.1007/s40518-014-0011-8

12. Fujii, S., Nishimoto, N., Notoya, A., Hellebust, J. A. 1995. Growth and osmoregulation of Chaetoceros muelleri in relation to salinity. Plant and Cell Physiology, 36(5), 759-764. doi: 10.1093/oxfordjournals. pcp.a078819

13. Gengmao, Z., Mehta, S., Zhaopu, L. 2010. Use of saline aquaculture wastewater to irrigate salt-tolerant Jerusalem artichoke and sunflower in semiarid coastal zones of China. Agricultural Water Management, 97(12), 1987-1993. doi: 10.1016/j. agwat.2009.04.013

14. Guillard, R. R., Ryther, J. H. 1962. Studies of marine planktonic diatoms: I. Cyclotella Nana Hustedt, and Detonula confervacea (Cleve) Gran. Canadian Journal of Microbiology, 8(2), 229-239. doi: 10.1139/ m62-029

15. Guo, Z., Liu, Y., Guo, H., Yan, S., Mu, J. 2013. Microalgae cultivation using an aquaculture wastewater as growth medium for biomass and biofuel production. Journal of Environmental Sciences, 25, S85-S88. doi: 10.1016/s1001-0742(14)60632-x

16. Hansen, H. P., Koroleff, F. 1999. Determination of dissolved inorganic phosphate. Methods of seawater analysis (3rd ed., pp. 170-180). Weinheim, Baden-Württemberg, Germany: Wiley-VCH Verlag GmbH. doi: 10.1002/9783527613984.ch10

17. Harrison, P. J., Thompson, P. A., Calderwood, G. S. 1990. Effects of nutrient and light limitation on the biochemical composition of phytoplankton. Journal of Applied Phycology, 2(1), 45-56. doi: 10.1007/ bf02179768

18. Hong, D. D., Mai, D. T. N., Thom, L. T., Ha, N. C., Lam, B. D., Tam, L. T. Anh, H. T. L. Thu, N. T. H. 2013. Biodiesel production from Vietnam heterotrophic marine microalga Schizochytrium mangrovei PQ6. Journal of Bioscience and Bioengineering, 116(2), 180-185. doi: 10.1016/j.jbiosc.2013.02.002

19. Klein-Marcuschamer, D., Chisti, Y., Benemann, J. R., Lewis, D. 2013. A matter of detail: Assessing the 
true potential of microalgal biofuels. Biotechnology and Bioengineering, 110(9), 2317-2322. doi: 10.1002/bit.24967

20. Krzemińska, I., Pawlik-Skowrońska, B., Trzcińska, M., Tys, J. 2014. Influence of photoperiods on the growth rate and biomass productivity of green microalgae. Bioprocess and Biosystems Engineering, 37(10), 2137-2137. doi: 10.1007/ s00449-014-1260-z

21. Kües, U. 2015. Fungal enzymes for environmental management. Current Opinion in Biotechnology, 33, 268-278. doi: 10.1016/j.copbio.2015.03.006

22. Lawton, R. J., Mata, L., de Nys, R., Paul, N. A. 2013. Algal bioremediation of waste waters from land-based aquaculture using Ulva: Selecting target species and strains. PLoS ONE, 8(10). doi: 10.1371/ journal.pone.0077344

23. Leonardos, N., Geider, R. J. 2004. Responses of elemental and biochemical composition of Chaetoceros muelleri to growth under varying light and nitrate:phosphate supply ratios and their influence on critical N:P. Limnology and Oceanography, 49(6), 2105-2114. doi: 10.4319/1o.2004.49.6.2105

24. Li, Y., Chen, Y.-F., Chen, P., Min, M., Zhou, W., Martinez, B., Zhu, J., Ruan, R. 2011. Characterization of a microalga Chlorella sp. well adapted to highly concentrated municipal wastewater for nutrient removal and biodiesel production. Bioresource Technology, 102, 5138-5144. doi: 10.1016/j. biortech.2011.01.091

25. López-Elías, J. A., Voltolina, D., Enríquez-Ocaña, F., Gallegos-Simental, G. 2005. Indoor and outdoor mass production of the diatom Chaetoceros muelleri in a mexican commercial hatchery. Aquacultural Engineering, 33(3), 181-191. doi: 10.1016/j. aquaeng.2005.01.001

26. Magnotti, C., Lopes, R., Derner, R., Vinatea, L. 2016. Using residual water from a marine shrimp farming BFT system. part I: nutrient removal and marine microalgae biomass production. Aquaculture Research, 47(8), 2435-2443. doi: 10.1111/ are. 12691

27. Malibari, R., Sayegh, F., Elazzazy, A. M., Baeshen, M. N., Dourou, M., Aggelis, G. 2018. Reuse of shrimp farm wastewater as growth medium for marine microalgae isolated from Red Sea - Jeddah. Journal of Cleaner Production, 198, 160-169. doi: 10.1016/j.jclepro.2018.07.037

28. Mandal, S., Mallick, N. 2011. Waste utilization and biodiesel production by the green microalga Scenedesmus obliquus. Applied and Environmental Microbiology, 77(1), 374-377. doi: 10.1128/ AEM.01205-10

29. Marinho-Soriano, E., Panucci, R. A., Carneiro, M. A. A., Pereira, D. C. 2009. Evaluation of Gracilaria caudata J. Agardh for bioremediation of nutrients from shrimp farming wastewater. Bioresource Technology, 100, 6192-6198. doi: 10.1016/j. biortech.2009.06.102

30. Miyajima, T., Tanaka, Y., Koike, I. 2005. Determining $15 \mathrm{~N}$ enrichment of dissolved organic nitrogen in environmental waters by gas chromatography/ negative-ion chemical ionization mass spectrometry. Limnology and Oceanography: Methods, 3, 164-173. doi: 10.4319/lom.2005.3.164

31. Mccarty, P. L., Bae, J., \& Kim, J. 2011. Domestic wastewater treatment as a net energy producer - can this be achieved? Environmental Science \& Technology, 45, 7100-7106. doi: 10.1021/es2014264

32. Meseck, S. L., Alix, J. H., \& Wikfors, G. H. 2005. Photoperiod and light intensity effects on growth and utilization of nutrients by the aquaculture feed microalga, Tetraselmis chui (PLY429). Aquaculture, 246(1-4), 393-404. doi: 10.1016/j. aquaculture.2005.02.034

33. Mondal, M., Halder, G., Oinam, G., Indrama, T., \& Tiwari, O. N. 2019. Bioremediation of organic and inorganic pollutants using microalgae. In New and Future Developments in Microbial Biotechnology and Bioengineering: Microbial Secondary Metabolites Biochemistry and Applications. Elsevier B.V. doi: 10.1016/B978-0-444-63504-4.00017-7

34. Msuya, F. E., \& Neori, A. 2002. Ulva reticulata and Gracilaria crassa: macroalgae that can biofilter effluent from tidal fishponds in Tanzania. Western Indian Ocean Journal of Marine Science, 1(2), 117-126.

35. Pate, R., Klise, G., \& Wu, B. 2011. Resource demand implications for US algae biofuels production scale-up. Applied Energy, 88(10), 3377-3388. doi: 10.1016/j.apenergy.2011.04.023

36. Raghavan, G., Haridevi, C. K., \& Gopinathan, C. P. 2008. Growth and proximate composition of the Chaetoceros calcitrans f. pumilus under different temperature, salinity and carbon dioxide levels. Aquaculture Research, 39(10), 1053-1058. doi: 10.1111/j.1365-2109.2008.01964.X

37. Rahmadi, A., Mulyani, Y., \& Lewaru, M. W. 2020. Effect of salinity difference on lipid content from Chaetoceros muelleri on continuous reactors. Advanced Journal of Graduate Research, 7(1), 3-10. doi: 10.21467/ajgr.7.1.3-10

38. Rai, M. P., Gautom, T., \& Sharma, N. 2015. Effect of salinity, $\mathrm{pH}$, light intensity on growth and lipid production of microalgae for bioenergy application. OnLine Journal of Biological Sciences, 15(4), 260-267. doi: 10.3844/ojbsci.2015.260.267

39. Raimbault, P., Diaz, F., Pouvesle, W., \& Boudjellal, B. 1999. Simultaneous determination of particulate organic carbon, nitrogen and phosphorus collected on filters, using a semiautomatic wet-oxidation method. Marine Ecology Progress Series, 180(1994), 289-295. doi: 10.3354/meps 180289 
40. Renaud, S. M., \& Parry, D. L. 1994. Microalgae for use in tropical aquaculture I: Gross chemical and fatty acid composition of twelve species of microalgae from the Northern Territory, Australia. Journal of Applied Phycology, 6(3), 337-345. doi: 10.1007/ BF02181948

41. Renaud, Susan M., Thinh, L. Van, Lambrinidis, G., \& Parry, D. L. 2002. Effect of temperature on growth, chemical composition and fatty acid composition of tropical Australian microalgae grown in batch cultures. Aquaculture, 211(1-4), 195-214. doi: 10.1016/S0044-8486(01)00875-4

42. Salama, M., Abou-Shanab, R. A. I., Kim, J. R., Lee, S., Kim, S.-H., Oh, S.-E., Kim, H.-C., Roh, H.-S., Jeon, B.-H. 2014. The effects of salinity on the growth and biochemical properties of Chlamydomonas mexicana GU732420 cultivated in municipal wastewater. Environmental Technology, 35(12), 1491-1498. doi: 10.1080/09593330.2013.871350

43. Sobczuk, T. M., Camacho, F. G., Grima, E. M., \& Chisti, Y. 2006. Effects of agitation on the microalgae Phaeodactylum tricornutum and Porphyridium cruentum. Bioprocess and Biosystems Engineering, 28(4), 243-250. doi: 10.1007/s00449-005-0030-3

44. Sode, S., Bruhn, A., Balsby, T. J. S., Larsen, M. M., Gotfredsen, A., \& Rasmussen, M. B. 2013. Bioremediation of reject water from anaerobically digested waste water sludge with macroalgae (Ulva lactuca, Chlorophyta). Bioresource Technology, 146, 426-435. doi: 10.1016/j.biortech.2013.06.062
45. Tanaka, Y., Ashaari, A., Mohamad, F. S., Lamit, N., 2020. Bioremediation potential of tropical seaweeds in aquaculture: low-salinity tolerance, phosphorus content, and production of UV-absorbing compounds. Aquaculture, 518, 734853. doi: 10.1016/j. aquaculture.2019.734853

46. Ummalyma, S. B., Pandey, A., Sukumaran, R. K., \& Sahoo, D. 2018. Bioremediation by Microalgae: Current and Emerging Trends for Effluents Treatments for Value Addition of Waste Streams. In Biosynthetic Technology and Environmental Challenges (pp. 355-375). Springer Nature Singapore. doi: 10.1007/978-981-10-7434-9_19

47. Wang, X., Liang, J., Luo, C., Chen, C., \& Gao, Y. 2014. Biomass, total lipid production, and fatty acid composition of the marine diatom Chaetoceros muelleri in response to different $\mathrm{CO} 2$ levels. Bioresource Technology, 161, 124-130. doi: 10.1016/j. biortech.2014.03.012

48. Yang, J., Li, X., Hu, H., Zhang, X., Yu, Y., \& Chen, Y. 2011. Growth and lipid accumulation properties of a freshwater microalga, Chlorella ellipsoidea YJ1, in domestic secondary effluents. Applied Energy, 88(10), 3295-3299. doi: 10.1016/j. apenergy.2010.11.029

49. Zhi, R., Yang, A., Zhang, G., Zhu, Y., Meng, F., \& Li, X. 2019. Effects of light-dark cycles on photosynthetic bacteria wastewater treatment and valuable substances production. Bioresource Technology, 274, 496-501. doi: 10.1016/j.biortech.2018.12.021 